\title{
Review:
}

\section{Within-litter variation in birth weight: impact of nutritional status in the sow*}

\author{
Tao-lin YUAN ${ }^{1}$, Yu-hua ZHU ${ }^{1}$, Meng SHI ${ }^{1}$, Tian-tian $\mathrm{LI}^{1}, \mathrm{Na} \mathrm{LI}^{1}$, Guo-yao WU', \\ Fuller W. BAZER ${ }^{2}$, Jian-jun $Z_{A N G}{ }^{1}$, Feng-lai WANG ${ }^{1}$, Jun-jun $W_{A N G}{ }^{\dagger 1}$ \\ ( ${ }^{1}$ State Key Laboratory of Animal Nutrition, College of Animal Science and Technology, China Agricultural University, Beijing 100193, China) \\ $\left({ }^{2}\right.$ Department of Animal Science, Texas A\&M University, College Station, Texas 77843, USA) \\ ${ }^{\dagger}$ E-mail: jkywjj@hotmail.com \\ Received Jan. 11, 2015; Revision accepted Apr. 9, 2015; Crosschecked May 7, 2015
}

\begin{abstract}
Accompanying the beneficial improvement in litter size from genetic selection for high-prolificacy sows, within-litter variation in birth weight has increased with detrimental effects on post-natal growth and survival due to an increase in the proportion of piglets with low birth-weight. Causes of within-litter variation in birth weight include breed characteristics that affect uterine space, ovulation rate, degree of maturation of oocytes, duration of time required for ovulation, interval between ovulation and fertilization, uterine capacity for implantation and placentation, size and efficiency of placental transport of nutrients, communication between conceptus/fetus and maternal systems, as well as nutritional status and environmental influences during gestation. Because these factors contribute to within-litter variation in birth weight, nutritional status of the sow to improve fetal-placental development must focus on the following three important stages in the reproductive cycle: pre-mating or weaning to estrus, early gestation and late gestation. The goal is to increase the homogeneity of development of oocytes and conceptuses, decrease variations in conceptus development during implantation and placentation, and improve birth weights of newborn piglets. Though some progress has been made in nutritional regulation of within-litter variation in the birth weight of piglets, additional studies, with a focus on and insights into molecular mechanisms of reproductive physiology from the aspects of maternal growth and offspring development, as well as their regulation by nutrients provided to the sow, are urgently needed.
\end{abstract}

Key words: Within-litter variation, Pig, Mortality, Morbidity, Growth, Sow nutrition doi:10.1631/jzus.B1500010 Document code: A CLC number: Q95

\section{Introduction}

Over the last few decades, selection for highly prolific sows has resulted in an increase in litter size (Quiniou et al., 2002); however, this is positively related to a substantial increase in pre- and post-natal mortality before weaning (Johnson et al., 1999) due to

\footnotetext{
Corresponding author

* Project supported by the National Basic Research Program (973) of China (No. 2012CB124703) and the National Natural Science Foundation of China (Nos. 31129006, 31272449, and 31422052) (D) ORCID: Jun-jun WANG, http://orcid.org/0000-0001-9427-3824 (C) Zhejiang University and Springer-Verlag Berlin Heidelberg 2015
}

greater within-litter variation in birth weights characterized by a higher proportion of low-birth-weight piglets in the litter (Milligan et al., 2002a; Quesnel et al., 2008; Kapell et al., 2011). There is a tendency for the proportion of runt piglets to be higher in litters in which birth weights of piglets are highly variable (van der Lende and Dejager, 1991). While small piglets are at greater risk of death than their larger littermates (Winters et al., 1947; Sharpe, 1966; Quiniou et al., 2002), survival of all piglets increases when there is reduced variation in birth weights of piglets within a litter (van der Lende and Dejager, 1991). At the same time, heterogeneity in birth weights of piglets among 
and within litters increases management costs in modern all-in-all-out swine production systems (Quiniou et al., 2002). Though some highly related factors such as genetic merit, oocyte quality, uterine capacity, and placental efficiency have been documented, the underlying mechanisms responsible for the high variability in birth weights within litters are unclear.

The aim of this review is to summarize the negative effects resulting from within-litter variation in birth weights, causative factors, and possible strategies for improving overall survival of piglets in large litters.

\section{Negative effects of within-litter variation in birth weight of piglets}

\subsection{Pre-weaning mortality}

Pre-weaning mortality is the major problem associated with improving prolificacy of sows. Approximately $15 \%-20 \%$ of piglets born do not survive to weaning (Fahmy and Bernard, 1971; Quiniou et al., 2002), and low birth weight is a primary contributor to poor survival to weaning (Winters et al., 1947; Pomeroy, 1960; Sharpe, 1966; Fahmy and Bernard, 1971; Bereskin et al., 1973; Pettigrew et al., 1986). Pre-weaning survival of piglets lighter than $0.45 \mathrm{~kg}$ was significantly lower than that of piglets weighing $1.6 \mathrm{~kg}$ or more (18\% vs. 97\%) (Fahmy and Bernard, 1971). Further, there is considerable evidence that high variation in birth-weight distribution in litters negatively skews the distribution in birth weights with the majority of piglets having birth weights well below the mean birth weight of the litter (Milligan et al., 2002b). In fact, there is a linear relationship between piglet survival and coefficient of variation for within-litter birth weight, and a curvilinear relationship between average birth weight and mortality of piglets (Fahmy and Bernard, 1971). Although there is also a favorable correlation between pre-weaning survival and within-litter variation in birth weight from the genetic perspective (Knol et al., 2002; Kapell et al., 2011), it is worth emphasizing that the adverse effects of high variation in birth weight on piglet survival are mainly due to an increase in the proportion of small piglets (Milligan et al., 2002a) since normal variation in birth weight has little effect on piglet survival in healthy litters (Milligan et al., 2001).

2.1.1 Intra-uterine growth restriction and susceptibility to infection and disease

Low-birth-weight piglets in litters with high variation in birth weights experience intra-uterine growth restriction (IUGR), usually resulting in physiological dysfunctions and an increase in neonatal morbidity and mortality (Wootton et al., 1983; Aucott et al., 2004). In addition, IUGR neonates are more susceptible to infection or environmental changes due to an ineffective immune system (Cromi et al., 2009; Zhong et al., 2012), and IUGR animals have abnormal differences in size and histopathology of the thymus (Cromi et al., 2009). Consistently, overexpression of heat shock protein 70 (Hsp70) associated with impaired cellular immunity was observed in the intestine (Zhong et al., 2010) and liver (Li et al., 2012) of IUGR neonates, suggesting that immune function is altered widely in IUGR piglets. There is growing evidence that elevated Hsp70 reduces proliferation and impairs nuclear factor-kappa B (NF- $\mathrm{B}$ ) signaling for cell survival (Wei et al., 1995; Ran et al., 2004).

\subsubsection{IUGR and hyperammonemia}

Abnormal metabolism of ammonia must be taken into consideration as a cause for morbidity or mortality of small piglets (Wu G. et al., 2010). We detected an abnormally high activity of glutamate oxaloacetate transaminase in the liver of IUGR fetuses compared with normal fetuses at Day 110 of gestation, this enzyme being responsible for the generation of ammonia from glutamate (Liu et al., 2013). High levels of expression of glutamate dehydrogenase 1, coupled with reduced levels of carbomoyphosphate synthase 1 to degrade it, result in the accumulation of ammonia, which increases the risk of hyperammonemia in low-birth-weight piglets and low-birth-weight human infants (Batshaw and Brusilow, 1978). This condition severely threatens survival of the neonate. Moreover, IUGR fetuses both at Days 90 and 110 of gestation had higher concentrations of ammonia in umbilical vein plasma than normal fetuses (Lin et al., 2012), which may account for poor survival and development of IUGR fetuses. The rate of protein degradation in the IUGR fetus may be higher than that in the normal-weight fetus. 


\subsubsection{IUGR and insufficient colostrum intake}

For low-birth-weight piglets, intake of colostrum is delayed and inadequate (Le Dividich et al., 1998; Quesnel et al., 2012), leading to a poor acquisition of passive immunity and a poor nutritional status, thereby increasing the incidence of death or poor growth performance of piglets during lactation (Rooke and Bland, 2002; Le Dividich et al., 2005). This is because colostrum is the most important source of highly digestible compounds for neonates, including glucose, fat, protein, immunoglobulins, hormones, and growth factors (Le Dividich et al., 2005) required to meet demands for energy of piglets and support maturation of the digestive and immune systems (Walzem et al., 2002; Politis and Chronopoulou, 2008). In addition, low-birth-weight neonates that have low energy reserves are at greater risk of being inadvertently crushed by the sow when she lies down (Fahmy and Bernard, 1971), as well as an inability to prevent chilling due to impaired thermogenic mechanisms (Le Dividich, 1999).

\subsection{Pre-weaning growth performance}

Differences in birth weights among piglets are also related to differences in pre-weaning growth performance within litters, which are mainly due to remarkable differences in both milk intake and efficiency of utilization of nutrients by littermates. Colostrum/milk intake is affected by both vitality of the piglet at birth and within-litter competition to access a teat as the teat order for suckling develops within the first $24 \mathrm{~h}$ after birth and is then maintained (McBride, 1963). Vigorous piglets prefer the anterior teats (Fraser et al., 1979; Thompson and Fraser, 1986), while small piglets are at a disadvantage in fighting to gain possession of these more productive anterior teats compared with their larger siblings since the teat order is a dominance hierarchy (Pond and Houpt, 1978; Auldist and King, 1995). However, per kg body weight, milk consumption does not appear to differ between IUGR and normal-weight piglets (Rezaei et al., 2011). Offspring that obtain milk from anterior and middle mammary glands (MGs) grow faster than those suckling posterior MG (Puppe and Tuchscherer, 1999; Kim et al., 2000). Besides the greater amount of colostrum and milk from anterior and middle MGs (Gill and Thomson, 1956), we reported that compo- nents in colostrum and milk secreted by anterior and posterior MGs are also distinctive (Wu W.Z. et al., 2010 ) in having proteins that are beneficial to passive immunity, intestinal development, and epithelial integrity; they include immunoglobulins and haptoglobin in colostrum and lactoferrin in milk from anterior $\mathrm{MG}$, which are more abundant in anterior and middle MGs compared with posterior MG. In addition, piglet body weight and stimulation through suckling intensity to the MG strongly determine milk production (King et al., 1997).

The inefficient utilization of nutrient was reported for small piglets (Rezaei et al., 2011) owing to physiological immaturity at birth, especially severe dysfunction in several organs, including the intestine (Wang X.Q. et al., 2014b), liver (Liu et al., 2013), and skeletal muscle (Wang T. et al., 2013). Additionally, concentrations of key proteins involved in growth and development were reduced, while there was an abundance of proteins associated with oxidative stress, proteolysis, and ATP hydrolysis in the small intestine, liver, and muscle of low-birth-weight piglets (Wang et al., 2008). Impaired development and dysfunction of those organs and tissues that play vital roles in digestion, absorption, and metabolism of dietary nutrients (Jobgen et al., 2006) could permanently decrease postnatal growth performance and efficiency of nutrient utilization in piglets. Therefore, these overall capacity differences in intake and utilization efficiency of nutrients among piglets may partly explain why differences in body weight at birth are often maintained or even increase throughout the period of lactation.

\subsection{Post-weaning growth and meat quality}

In litters in which there is a high variability among piglets regarding birth weight, growth rates among those offspring are desynchronized. Litters with more variability in piglet weight at birth have more variable weaning weights (Thompson and Fraser, 1986; Milligan et al., 2001; 2002b), since birth weight, absolute body-weight gain during lactation and weight at weaning are highly correlated (Quiniou et al., 2002). As an unfavorable consequence, the time for pigs within a litter to achieve slaughter weight is variable, with an additional three weeks being required for small piglets to reach $25 \mathrm{~kg}$ compared with their heavier littermates (76 and $55 \mathrm{~d}$, respectively) (Quiniou et al., 2002). These differences can result in 
an increase in feed and management costs for lighter pigs due to the longer time and increased feed required for them to reach the required minimum commercial slaughter weight.

The distribution of muscular fiber type for IUGR piglets is affected negatively (Widdowson, 1971; Wigmore and Stickland, 1983; Wu et al., 2006) as both secondary and total muscle fibers are reduced in number (Wigmore and Stickland, 1983; Wang T. et al., 2013) for small fetuses, which, in turn, adversely affects growth rate and post mortem quality of meat. The reduction in number of muscular fibers and the larger diameters for those fibers for IUGR piglets result in greater amounts of intramuscular lipids and decreased meat tenderness at slaughter (Gondret et al., 2005), leading to a decrease in meat quality and economic losses.

\section{Causes for within-litter variation in birth weight}

Knowledge of the underlying mechanisms responsible for various distributions in birth weights of piglets within litters has important implications for the prevention of small neonates and is crucial for enhancing the efficiency of livestock production and animal health. Growth and development of the fetus involve numerous complex biological events that can be influenced by genetics, epigenetics, maternal maturity, state of maternal nutrition, and environmental temperatures (Redmer et al., 2004). These factors affect implantation and placentation by the conceptus, angiogenesis within the uterus and placenta, utero-placental efficiency of transport of nutrients, and activities of fetal metabolic pathways (Bell and Ehrhardt, 2002; Fowden et al., 2005; Reynolds et al., 2006). All of those events may be influenced by breed characteristics that include maturity of ovulated oocytes, duration of ovulation, implantation and placentation capacity, available uterine space for implantation and placentation, size and efficiency of the placenta, as well as nutritional provision and environmental influences on the sow (Wu et al., 2006).

\subsection{Duration of ovulation and oocyte maturation}

The duration of ovulation, known as the time interval between ovulation of the first and the last follicle in a sow, and follicular diversity are believed to be associated with diversity in embryonic development during early pregnancy (Pope et al., 1990). Furthermore, the sequence of oocyte release during ovulation might contribute to differences in embryonic development with later-ovulated oocytes $(42 \mathrm{~h}$ after human chorionic gonadotropin (hCG) injection) producing less-developed embryos at Day 4 of pregnancy, compared with earlier-ovulated oocytes $(39 \mathrm{~h}$ after hCG injection); not surprisingly, the lessdeveloped Day 4 embryos became the smaller blastocysts within a litter at Day 12 of gestation (Xie et al., 1990). In terms of hormone levels being key predictors of embryonic development, the more-developed blastocysts synthesize estradiol sooner than their contemporaries (Geisert et al., 1982a; Pope et al., 1988), while less-developed embryos at Day 12 of gestation contained less estradiol, less total protein, and less acid phosphatase activity (Xie et al., 1990), which might influence elongation and implantation of blastocysts. At the same time, the duration of ovulation in Meishan sows is $2 \mathrm{~h}$ versus $6 \mathrm{~h}$ for Large White sows, and this shorter interval was associated with less morphological variation and increased embryonic survival in litters of Meishan gilts (Bazer et al., 1988). Moreover, when later-ovulated follicles were removed, the diversity in embryonic morphology was reduced concomitantly, mainly through eliminating less-developed embryos (Pope et al., 1988). Further, duration of ovulation is related to the pattern of ovulation, since the distribution of follicular development and oocyte maturation are both skewed with a majority of mature follicles and oocytes (e.g. 70\%) being ovulated during a short period of time and the rest (e.g. $30 \%$ ) being ovulated during the following 2-6 $\mathrm{h}$ (Pope et al., 1990).

In contrast, Soede et al. (1992) concluded that embryonic diversity was not related to the duration of ovulation, at least up to $3 \mathrm{~h}$, as they observed no significant differences in numbers of nuclei or numbers of cell cycles about $100 \mathrm{~h}$ after ovulation between Groups A and B (duration of ovulation was (1.8 \pm 0.6 ) and (4.6 \pm 1.7$) h$ in Groups A and B, respectively). The reasons for these differences in results may include the maturation and quality of oocytes, as well as endocrine status of the sows. It is clear that embryonic diversity throughout at least the first $12 \mathrm{~d}$ of gestation is predetermined by factors that involve follicular 
development and oogenesis (Pope et al., 1990; Xie et al., 1990). Furthermore, oocyte maturation and quality can affect embryonic development and hormone secretion by the conceptus ultimately affecting the endocrine status of the uterus (Bazer et al., 2014). More studies are warranted to gain further insight into relationships between duration of ovulation and variations in embryonic development, although a body of evidence supports the view that the oocytes of later-ovulated follicles could be progenitors of small embryos.

\subsection{Implantation capability of conceptuses and position within the uterus}

The relationship between the fetal-placental growth and location within the uterus is evident. Pig fetuses from the ovarian end of the horn were approximately $10 \%$ heavier than those located at the middle or near end of the cervix (Waldorf et al., 1957; Perry and Rowell, 1969; Wise et al., 1997), and similar results have been described in rabbits (Rosahn and Greene, 1936). The effects of location within the uterine horn on fetal piglet weight are more notable during the last one-third of gestation when the demand for transfer of nutrients from the maternal system across the placenta to the fetus is greatest. Kim et al. (2013) concluded that fetal weight decreased linearly from the utero-tubal junction to the cervix between Days 102 and 112 of gestation. It is postulated that vascular density within the placenta varies from uterine horn to cervix, that blood flow increases from the cervical to the oviductal end of each uterine horn in gilts during early pregnancy (Ford et al., 1982), and that implantation sites with less than three blood vessels were associated with poor development of the fetus which increased fetal weight variation within the litter. Moreover, it has been observed that there is considerable diversity in development of conceptuses prior to implantation within litters (Anderson, 1978; Geisert et al., 1982a), which may contribute to differences in timing and capacity to establish adequate surface area for implantation and placentation, since elongation of the conceptus during the peri-implantation period of pregnancy is critical to implantation and depends on the conceptus achieving a specific stage of differentiation and development (Anderson, 1978; Stroband and van der Lende, 1990; Blomberg et al., 2010).

\subsection{Placental efficiency}

Maternal nutrition during gestation, especially the amount of nutrients provided to each conceptus, has been regarded as a major cause for within-litter variation in birth weight of piglets currently born to sows. Fetuses acquire nutrients from the maternal system via the utero-placental circulation and umbilical vein throughout gestation (Kiserud and Acharya, 2004), and transfer of nutrients from mother to fetus is impaired in pregnancies with reduced blood flow in piglets which exhibit signs of IUGR (Reynolds et al., 2006; Kim et al., 2013). Furthermore, the composition of nutrients, gases, and other molecules in the umbilical vein blood is different between normal and IUGR fetuses. Previous results from our laboratory indicated lower circulating concentrations of glucose, amino acids of the arginine family, such as arginine and glutamine, and branched-chain amino acids (valine, leucine, and isoleucine), but increased concentrations of ammonia in umbilical vein plasma during late gestation in IUGR, compared with normal fetuses (Lin et al., 2012). It is clear that the transport of nutrients by the placenta of IUGR fetuses is altered and directly impairs fetal development (Wu et al., 2008).

\subsection{Available uterine space}

Increase in ovulation rates for gilts and sows during the past decades is a positive response to continuous selective breeding; however, as the number of conceptuses that survive during the post-implantation period greatly exceeds uterine capacity, there is a decrease of available uterine surface area for the development of each placenta. Therefore, there is a peak in post-implantation conceptus deaths between Days 30 and 50 of gestation when uterine surface area is insufficient (Knight et al., 1977; Vonnahme et al., 2002). As gestation progresses, the negative effects of limited uterine space on fetal development also increase (Vonnahme et al., 2002). The great within-litter variation in birth weight and increased proportion of small piglets born to the highly prolific sows as used today are likely related, in part, to intra-uterine crowding from at least the end of the first month of gestation (Foxcroft et al., 2006), especially when there are more than 14 fetuses present within the uterus (Webel and Dziuk, 1974). Moreover, intrauterine crowding can alter the pattern of development 
of fetal muscle fibers in the immediate postimplantation period (Foxcroft et al., 2007), when mesenchymal stem cells of the embryo undergo differentiation for myogenesis, adipogenesis or mesenchymal cells (Cossu and Borello, 1999; Du et al., 2010). Detrimental effect of uterine crowding on fetal development (Town et al., 2004) is considered to be associated with insufficient development of placental vascularity (Argente et al., 2008), while a poor vascular supply and reduced uterine space limit development of offspring that thereby experience a deficit in nutrient availability before birth (Argente et al., 2006; Foxcroft et al., 2007). This subsequently increases within-litter variation in birth weight that is associated with greater post-natal death of piglets.

\subsection{Breed characteristics}

There is a body of evidence implying that genetic merit does exert considerable effects on litter homogeneity, as fetal genotype determines placental and endometrial vascularity during the last one-third of gestation (Biensen et al., 1998). Convincing data revealed that development of Meishan conceptuses was more uniform between Days 8 and 14 of gestation (Bazer et al., 1988), and within-litter variation in birth weight was lower in Meishan litters than in Large White litters (Lee and Haley, 1995). Differences in growth patterns for placentas and uterine capacity (Père and Etienne, 2000) between the two breeds can account for a large portion of the significant differences in birth-weight distribution. The Meishan placentas are smaller at farrowing (Wilson et al., 1998), while vascular density progressively increases between Days 90 and 110 of gestation with constant placental size. In contrast, Large White placental size progressively increased during late gestation, while vascular density remained constant (Biensen et al., 1998; Wilson et al., 1998). Hence, endometrial surface area per Meishan placenta decreased and competition among fetuses reduced simultaneously, which is associated with the high degree of uniformity in birth weight within litters of Meishan sows.

Within-litter variation in birth weight is also affected by parity, with older sows with greater parity often having less uniform litters as well as a higher proportion of low-birth-weight piglets (Damgaard et al., 2003; Quesnel et al., 2008; Wientjes et al., 2012). Pettigrew et al. (1986) also reported that birth weights of piglets from primiparous sows were more uniform. Litter size is positively correlated with parity, reaching the highest level between parities 3-5 (Dewey et al., 1995; Hughes, 1998). However, negative effects of parity on litter homogeneity may be related to its effects on litter size, which is positively related to within-litter variation in birth weight especially in litters with more than a total of 16 piglets born (Quiniou et al., 2002; Quesnel et al., 2008; 2014). An opposite view held by Pettigrew et al. (1986) is that the apparent increase in piglet birth weight standard deviation associated with increased litter size was far from enough to explain the impacts of parity on litter uniformity. Moreover, variation in birth weight is greater in older parity sows after correction for the total number of piglets born and excluding the effects of litter size (Wientjes et al., 2012). It has been postulated that the decrease in litter uniformity in older parity sows may result from deterioration in quality of follicles/oocytes with aging as reported for women (Broekmans et al., 2009), suggesting that litter uniformity in birth weight can also be affected solely by parity.

It follows that within-litter variation in birth weight is an integrated trait influenced by many factors. Additionally, these factors can interact with each other. Thus, studies focusing on within-litter variation in birth weight are in their infancy, and more studies are needed to clarify mechanisms and develop strategies to decrease IUGR in modern sows.

\section{Strategies to decrease within-litter varia- tion in birth weight}

Pregnancy outcome is influenced by interactions between nutrition and genetics (Wu et al., 2006). For specific breeds in swine production, the sow's nutrition is attracting the most research interest with a promise of decreasing within-litter variation in birth weight. Since there are three critical stages associated with conceptus/fetus survival and development throughout gestation, nutritional strategies that focus on pre-ovulation, peri-implantation and late gestation periods are expected to increase developmental homogeneity of oocytes and/or conceptuses, and decrease variations in the capability of conceptuses to undergo successful implantation and placentation, so 
that the birth weights of newborn piglets are more uniform. Improving litter uniformity is expected to increase the number of piglets born alive, as well as survival of piglets pre- and post-weaning and their growth performance after weaning.

\subsection{Nutrition related to follicle/oocyte maturity}

There is evidence that events during oogenesis influence survival and development of swine embryos (Pope et al., 1990), since oocyte maturity may be a determinant of uniformity in embryonic development, and subsequently, within-litter variation in birth weight (van der Lende et al., 1990). Therefore, nutritional strategies directed at sows prior to mating hold great promise to decrease within-litter variation in birth weight.

\subsubsection{Energy intake}

Energy intake should be regarded as the intake of lipids, carbohydrate, and amino acids in diets, as well as the ratios of these nutrients. Thus, knowledge of nutrient metabolism is essential to understand the utilization and function of dietary energy. Energy is critical for reproductive performance in swine. Sows fed low-energy diets during the weaning-to-estrus interval exhibit lower ovulation rates (Zak et al., 1997; van den Brand et al., 2000), smaller follicle size and fail to exhibit strong signs of estrous behavior (Prunier et al., 1993). However, modestly high-energy diets for sows pre-mating have positive impacts on embryonic survival (Ferguson et al., 2006) and litter homogeneity (Ashworth et al., 1999). Blastocysts recovered at Day 12 of gestation from gilts on a high level of feed intake pre-mating $(3.5 \mathrm{~kg} / \mathrm{d})$ exhibited a lower within-litter standard deviation in blastocyst surface area, compared with blastocysts from gilts fed a maintenance diet pre-mating $(1.15 \mathrm{~kg} / \mathrm{d})$, indicating that increasing pre-mating feed intake can reduce within-litter variability in blastocyst size at Day 12 of pregnancy (Ashworth et al., 1999). In addition, variation in body weight was less for sows fed $150 \mathrm{~g} / \mathrm{d}$ dextrose-supplemented diets, compared with sows fed general diets during the weaning-to-estrus interval (van den Brand et al., 2006). Similar results were obtained in response to dietary supplementation with dextrose plus lactose from the last week of gestation until sows were inseminated (van den Brand et al., 2009).

\subsubsection{Energy and insulin/IGF-1}

Within-litter variation in birth weight reduced through dietary manipulation during the follicular phase of the estrous cycle (van den Brand et al., 2006; 2009) is likely due to improved follicle and oocyte development associated with changes in concentrations of metabolic hormones such as insulin-like growth factor-1 (IGF-1) and insulin (Yang et al., 2000; Ferguson et al., 2003). Development of follicles and oocytes is improved owing to higher concentrations of insulin (Matamoros et al., 1990; Tokach et al., 1992; van den Brand et al., 1998; 2000; Ziecik et al., 2002) or IGF-1 in plasma (Ferguson et al., 2003). The underlying mechanism by which insulin increases follicular development is possibly due to an increase in luteinizing hormone (LH) pulsatility (Cox et al., 1987) or LH production (Adashi et al., 1981), and a higher LH pulse frequency (van den Brand et al., 2000).

\subsubsection{Energy source}

Effects of feeding level on reproductive performance depend on dietary energy. Follicle quality or oocyte maturation can be stimulated by carbohydraterich diets, but decreased by fat-rich diets (van den Brand et al., 2006), which can be explained partially by different ingredients in feed that affect different reproductive hormones (van den Brand et al., 2000). Feeding a carbohydrate-rich diet during and after lactation increases the pre-ovulatory LH peak and circulating concentrations of progesterone in comparison with feeding a fat-rich diet (Kemp et al., 1995). On the other hand, plasma insulin levels increase more rapidly in gilts fed dextrose than fat, which results in a significant difference in plasma insulin at 24 min after feeding (van den Brand et al., 1998). Furthermore, feeding a high fiber diet during the estrous cycle tends to increase embryonic survival and decrease the proportion of IUGR fetuses at Day (27 \pm 2 ) of gestation (Ferguson et al., 2006). This may be due to a longer time for energy or some fiber-related metabolites to enhance oocyte quality or follicular development.

\subsubsection{Vitamin A/retinol}

Vitamins function as micronutrients with extensive participation in metabolic processes. Alterations 
in dietary retinol could improve pregnancy outcome by decreasing both the incidence of low-birth-weight piglets and within-litter variation in birth weight (Whaley et al., 2000; Antipatis et al., 2008). Treatment of sows with vitamin A at weaning increased subsequent litter size through decreased embryonic mortality (Coffey and Britt, 1993) and synchronous development of embryos (Pope et al., 1990). Whaley et al. (2000) found that embryonic development was more advanced and more uniform when dietary supplementation with $1 \times 10^{6}$ IU vitamin A (retinyl palmitate) was provided from Day 15 after the second estrus until mating at the third estrus. Similarly, more embryos with greater uniformity were obtained at Day 11 of gestation from gilts treated with vitamin A before mating (Whaley et al., 1997). Positive effects of vitamin A are considered to be associated with enhanced maturation of oocytes (Robertson, 1997; Robertson et al., 1997) and, consequently, enhanced embryonic development (Besenfelder et al., 1996). Further, concentrations of progesterone, IGF-1, and prostaglandin F2- $\alpha$ (PGF2- $\alpha$ ) in follicular fluid were greater in vitamin-A-treated than in control gilts. Effects of vitamin A on follicle maturation were suggested to be through an IGF-1 stimulatory mechanism, since IGF-1 produced by granulosa cells plays a key role in the resumption of oocyte meiosis (Hammond et al., 1991) and increases both proliferation and progesterone synthesis and secretion by granulosa cells (Giudice, 1992).

\subsection{Nutrition related to the peri-implantation period of pregnancy}

Maternal recognition of pregnancy and conceptus implantation are the most important biological events associated with the establishment of pregnancy (Perry et al., 1976). Estrogen secreted by pig conceptuses is the major signal for maternal recognition of pregnancy at approximately Day 11 of gestation (Dhindsa and Dziuk, 1968; Perry et al., 1973; Bazer and Thatcher, 1977; Flint et al., 1979), which coincides with the time of conceptus elongation (Heap et al., 1979; Geisert et al., 1982b). Moreover, the morphological transition of conceptuses from spherical to tubular and filamentous forms occurs between Days 10 and 12 (Geisert et al., 1982b; Bazer and Johnson, 2014).

Implantation is a gradual process starting as early as Day 13 when elongation of the conceptus is underway and is well advanced by Day 18 of gestation (Perry et al., 1976), which is a determinant for establishing sufficient uterine surface area for placentation and subsequent nutrient transport for piglet survival and development (Geisert et al., 2014; Bazer and Johnson, 2014). It should be emphasized that establishment of pregnancy (conceptus elongation and implantation) also involves maternal uterine pro-inflammatory and immune responses (Geisert et al., 2014), due to a number of cytokines released or stimulated by the elongating conceptuses, such as NF- $\kappa$ B (Hayden and Ghosh, 2012) and interleukin $1 \beta$ (IL-1 $\beta$ ) (Ross et al., 2003; Blomberg et al., 2005). In order to avoid rejection by the immune response, an increase in expression of both IL1B and estrogen by individual conceptuses counter-balances stimulation of the pro-inflammatory and immune response within the uterus (Geisert et al., 2014); thus elongating conceptus can attach across the uterine luminal epithelial surface successfully.

As stated above, elongation of pig conceptuses is triggered by the conceptus achieving a specific stage of differentiation and development within the uterus (Bazer et al., 2014). Thus, it is a maternal event and has never been achieved in vitro (Anderson, 1978; Stroband and van der Lende, 1990; Blomberg et al., 2010; Bazer, 2013). However, various stages of conceptus development (spherical, tubular and filamentous) can be observed prior to and during the time of trophoblast elongation within the same litter (Anderson, 1978; Geisert et al., 1982a), leading to remarkable differences in timing, position, and area of implantation, and, thereafter, various states of survival and development. It is worth noting that pre-implantation embryonic losses are considered to make up the largest proportion of prenatal losses in pigs (Wiseman et al., 1998), suggesting that this is a key period to regulate embryonic survival and development during the implantation window and to affect placentation.

\subsubsection{L-Arginine}

Dietary supplementation with $0.4 \%$ or $0.8 \%$ L-arginine between Days 14 and 25 of gestation increased number of viable fetuses per litter by 2 on Day 25 compared with a control group (Li et al., 2014). This positive result is consistent with the presence of unusually high concentrations of amino acids in the arginine family in porcine allantoic fluid 
at the stage of blastocyst expansion and implantation in vivo (Wu et al., 1996; Gao et al., 2012) and of an increase in endometrial angiogenesis between Days 13 and 18 of gestation (Keys et al., 1986). Furthermore, arginine stimulates the AKT1-mTOR/FRAP1-RPS6KRPS6 cell signaling pathways to increase proliferation and migration of porcine (Kong et al., 2012) and ovine (Kim et al., 2011) trophectoderm cells during peri-implantation period. The positive impact of L-arginine supplementation during the peri-implantation period of pregnancy is due in part to the production of $\mathrm{NO}$, since this is crucial for embryonic development and implantation (Maul et al., 2003; Wang X.Q.et al., 2014a). Putrescine, which is a product of arginine catabolism in maternal tissues (Wu et al., 2009), can also stimulate protein synthesis in porcine placental cells (Kong et al., 2014). Of note, dietary supplementation of $0.8 \%$ L-arginine between Day 0 and Day 25 of gestation reduced litter size, uterine weight, total number of fetuses, number of corpora lutea and total fetal weights significantly at Day 25 (Li et al., 2010). Even though there was increased vascularity of the uterus due to arginine supplementation, its administration too early (from onset of estrus) interfered with normal ovulation, which decreased production of progesterone and estrone (Li et al., 2010). From these aspects, dietary supplementation with L-arginine during the peri-implantation period is expected to promote survival and synchronize development of embryos within a litter.

\subsubsection{Retinol/vitamin A}

Providing a vitamin A-deficient diet for $100 \mathrm{~d}$ prior to mating and during the first month of pregnancy increased the uniformity of birth weights and showed a tendency to decrease the incidence of lowbirth-weight piglets (Antipatis et al., 2008). Moreover, sows on vitamin A-deficient diets did not experience a reduction in fetal survival and growth at Day 30 of pregnancy (Ashworth and Antipatis, 1999), perhaps due to a compensatory increase in the abundance of retinol binding protein (RBP) (Antipatis et al., 2008). Since pig conceptuses secrete RBP prior to onset of elongation and throughout the peri-implantation period, RBP could be an important component of the uterine secretions for early embryonic development (Harney et al., 1990; Schweigert et al., 1999). Thus, elevated levels of RBP in gilts deficient in vitamin A can account for positive outcomes of piglets having low within-litter variation in birth weight.

It is well documented that progesterone is required to maintain pregnancy and circulating concentrations of progesterone can be modulated by feed intake. Sows receiving high $((2.8 \pm 0.02) \mathrm{kg} / \mathrm{d})$ nutrient intake, compared with a low $((1.5 \pm 0.01) \mathrm{kg} / \mathrm{d})$ nutrient intake, from Day 0 to Day 9 of pregnancy had higher embryonic survival at Day 10 of pregnancy $((92 \pm 3) \%$ vs. $(77 \pm 3) \%)$ (Athorn et al., 2013), which may be due to higher concentrations of blood progesterone in response to adequate feed intake. Progesterone synthesis is likely to be impaired when dietary intake of nutrients (particularly amino acids) and energy is insufficient.

\subsection{Nutrition related to fetal growth during late gestation}

Approximately $90 \%$ of fetal growth occurs during the last one-third of pregnancy. This period of pregnancy is characterized by a high incidence of limitations on fetal development and increased withinlitter variation in fetal weight. The weight variation among piglets in each litter increased from Day 45 to Day 60 of gestation (Kim et al., 2009). After implantation, the placenta is the only organ through which nutrients, waste and respiratory gases are exchanged between the sow and conceptus (Faber and Thornburg, 1983). The size and capacity of the placenta for nutrient transfer play key roles in determining the prenatal growth of the fetus and hence affect birth weight directly (Redmer et al., 2004). Placentation that occurs during early pregnancy is one of the most important developmental events (Boshier, 1969; King et al., 1982), since it is tightly associated with embryonic survival (Reynolds and Redmer, 2001). Extensive angiogenesis occurs in both the maternal uterus and fetal placenta during placentation, and umbilical blood flow increases during the same time (Reynolds et al., 1984; Reynolds and Redmer, 1992; 1995). It has been reported that early embryonic mortality increases as placental vascular development decreases (Meegdes et al., 1988; Reynolds and Redmer, 1995). Therefore, adequately balanced diets provided to sows and functional nutrients available for placental transport are two major factors affecting uniformity of piglets in a litter during late gestation. Supplementation of diets with functional 
amino acids (e.g. arginine and glutamine) holds great promise for preventing fetal growth restriction $(\mathrm{Wu}$ et al., 2013a; Lin et al., 2014).

\subsubsection{L-Arginine/ $N$-carbamyl-L-glutamate}

Amino acids in the arginine family (arginine, glutamine, glutamate, proline, aspartate, asparagine, citrulline, and ornithine) have been studied extensively given their prominent effects in improving litter size (Greenberg et al., 1997; Hazeleger et al., 2007; Mateo et al., 2007; Gao et al., 2012; Li et al., 2014). At the same time, dietary supplementation with $25.5 \mathrm{~g} / \mathrm{d}$ L-arginine from Day 77 of pregnancy until term reduced within-litter variation in birth weight of live-born piglets by $20.6 \%$ and $25.4 \%$ in arginine and control groups, respectively (Quesnel et al., 2014). Dietary supplementation with $0.1 \%$ $\mathrm{N}$-carbamyl-L-glutamate (NCG) from Day 90 of gestation also increased litter size born alive and total litter weight for piglets born alive (Liu et al., 2012).

L-Arginine is an important precursor for the synthesis of $\mathrm{NO}$ and polyamines ( $\mathrm{Wu}$ and Morris, 1998; Wu et al., 2007; Blachier et al., 2011), both of which play key roles in placental growth and angiogenesis (Wu et al., 2006). Similarly, NCG stimulates expression of vascular endothelial growth factor (Liu et al., 2012) associated with vasculogenesis and angiogenesis (Hanahan, 1997; Arroyo and Winn, 2008). Subsequently, NCG increases blood flow and placental efficiency (McCrabb and Harding, 1996; Gardner et al., 2001), as well as the provision of nutrients to fetuses. Therefore, nutrient partitioning among fetuses is less variable as is within-litter variation in birth weight of piglets. However, there are other reports that do not indicate positive effects of dietary supplementation with L-arginine during mid-gestation to term on within-litter uniformity (Mateo et al., 2007; Gao et al., 2012). These different findings may be explained by differences in the total amounts of dietary L-arginine and other amino acids consumed by gestating pigs (Wu et al., 2013b; 2013c).

As previously mentioned, either dextrose supplementation during the weaning-to-estrus interval or $1 \%$ L-arginine supplementation during the last one-third of gestation can reduce within-litter variation in birth weights (van den Brand et al., 2006; Quesnel et al., 2014). Unexpectedly, combined sup- plies of dextrose beginning one week before insemination and L-arginine during the last one-third of pregnancy in sow diets had no obvious beneficial effects on within-litter variation in birth weight, compared with control groups (Quesnel et al., 2014). This was postulated to be correlated with complex interactions between different nutrients. High levels of glucose can affect amino acid metabolism and, therefore, may not be beneficial for embryonic and fetal survival, growth, or development. Thus, consideration must be given to interactions among different nutrients when manipulating maternal diets during gestation.

\subsubsection{Glutamine}

As a member of the arginine family of amino acids, glutamine plays a key role in many metabolic processes, such as cell proliferation, differentiation, and embryonic development (Petters et al., 1990; Wu et al., 2011). Concentrations of glutamine are highest among amino acids in fetal tissues and maternal placenta (Self et al., 2004), and there are increased concentrations of glutamine in allantoic fluid in the second third of gestation (Wu et al., 1996), which highlights the importance of glutamine during that stage of rapid placental and fetal growth.

Within-litter variation in weight of piglets can also be reduced by dietary supplementation with glutamine (Wu et al., 2010). Sows fed a basal gestational diet supplemented with mixture of $8 \mathrm{~g}$ L-arginine and $12 \mathrm{~g} \mathrm{L-glutamine} \mathrm{had} \mathrm{reduced} \mathrm{within-}$ litter variation in birth weight either on the basis of total piglets or live-born piglets, and the proportion of runt piglets was decreased. It would be of interest to determine whether dietary supplementation with L-glutamate, which is the immediate precursor of L-glutamine (Rezaei et al., 2013b) and is another functional amino acid (Wu, 2010), can enhance fetal growth and reduce birth-weight variation among piglets.

\subsubsection{Branched chain amino acids}

Branched chain amino acids (BCAAs), including leucine, isoleucine, and valine, have received growing attention owing to their emerging functional importance (Lei et al., 2012; 2013). These amino acids are substrates for the synthesis of glutamate and arginine, and, therefore, alanine, citrulline, arginine, 
and proline in pigs (Rezaei et al., 2013a) and ruminant species (Wu et al., 2014). Data from our laboratories suggest that dietary supplementation with BCAAs throughout pregnancy can reverse IUGR in a rat model of malnutrition (Zheng et al., 2009). In litters derived from BCAA-supplemented gestating sows, weights of piglets and placentas increase by $18.4 \%$ and $18.0 \%$, respectively, and litter size is also increased. Furthermore, BCAA treatment increased IGF-1 in embryonic liver, estrogen receptor- $\alpha$ and progesterone receptor in the uterus, and IGF-II in placentas, all of which are beneficial to survival and growth of the conceptus. There was also enhanced expression of two key enzymes (fructose-1,6biphosphatase and phosphoenolpyruvate carboxykinase) involved in gluconeogenesis in embryonic livers. These positive findings indicate that BCAAs have important roles in enhancing positive pregnancy outcomes.

Fetal growth is affected by the nutritional, metabolic and endocrine status of the maternal system which is affected by dietary intake of nutrients (Lin et al., 2014). Moreover, nutrient requirements of sows are distinct at different stages of gestation (Kim et al., 2013). Therefore, more studies to gain insight into the molecular mechanism for the role of maternal nutrients on fetal programming are necessary for designing innovative nutrient-balanced gestational diets that enhance the homogeneity of birth weight of piglets.

\subsection{Genetic selection}

Litter size, directly related to productivity, has been considered as a key factor in genetic selection. As a result, the total number of piglets at birth has been significantly improved in past decades (Southwood and Kennedy, 1991; Estany and Sorensen, 1995). However, this practice has also increased the neonatal mortality of piglets owing to the increased percentage of low-birth-weight pigs (Lund et al., 2002). To avoid this situation, scientists have started to test whether litter size at Day 5 (LS5) after birth can be used to reduce the neonatal mortality while not decreasing the litter size at birth. Recent results from 42807 Landrace and 33225 Yorkshire sows showed a significant genetic and phenotypic improvement in the total number of piglets at birth and neonatal survival (Nielsen et al., 2013), as well as litter size at weaning (Su et al., 2007; EAAP, 2011) by using LS5 as an index of genetic selection. Therefore, this criterion has been extended for use in the Danish Landrace and Yorkshire breeding program since 2004 (Nielsen et al., 2013). At the same time, a maternal line selected on litter size at weaning in rabbits for 21 generations improved the number of progeny born alive and litter size at weaning, compared with selection on litter size at birth (García and Baselga, 2002), suggesting that it is effective in both promoting litter size at birth and survival rate during lactation (Savietto et al., 2014). Additionally, it is feasible to select for within-litter uniformity in birth weight (Damgaard et al., 2003; Kapell et al., 2011) to improve piglet survival (Canario et al., 2010). A selection experiment on within-litter birth-weight variation in rabbits yielded a favorable response and decreased pre-weaning morbidity (Garreau et al., 2004). Collectively, genetic selection by combining litter uniformity at birth, survival rate during lactation, and litter size at weaning holds a promise of improving pig productivity.

\section{Summary and perspectives}

Currently, special attention is given to withinlitter variation in birth weight, as a distinct problem in modern highly prolific sows. Heterogeneity is a problem mainly for piglets with low birth weight that have suffered from IUGR (Foxcroft et al., 2006), which is associated with high pre-weaning mortality, variable weights at weaning, and poor growth performance post-weaning, resulting in lower production efficiency and economic losses. Furthermore, withinlitter homogeneity in birth weight may also be related to a decrease in stillbirths (Damgaard et al., 2003; Canario et al., 2006). In this context, the development of strategies that reduce within-litter variation in birth weight or unfavorable traits that are negatively related to piglet survival is essential for sustaining the pig industry. Since the degree of heterogeneity within litters increases as a response to selection for litter size (Johnson et al., 1999), genetic selection on litter size should be accompanied by selection on piglet survival traits (losses from birth to weaning and the minimal birth weight in the litter, which are proposed as potential traits for a selection against piglet mortality) and birth-weight traits (Wolf et al., 2008). On the other hand, identifying the physiological and 
biochemical mechanisms responsible for variation in litter birth weight and optimizing maternal nutrition to support requirements for growth and development of conceptuses is essential. Research focused on regulation of litter homogeneity is in its infancy, and therefore, more researches are essential to better understand the cellular and molecular mechanisms by which certain nutrients regulate metabolic pathways and embryonic/fetal development. It should also be borne in mind that nutrient interactions (e.g. ratios of amino acids, carbohydrate, and fatty acids) affect within-litter variation in birth weight. Finally, gestating swine requires not only proteinogenic amino acids that cannot be synthesized in animal cells but also proteinogenic and possibly non-proteinogenic amino acids that can be synthesized in the body to support their maximum reproductive performance (Wang W.W. et al., 2013; Wu, 2014). These synthesizable, functional amino acids include L-arginine, L-glutamine, L-proline, and glycine (Wang W.W. et al., 2014; $\mathrm{Wu}, 2013$ ) to improve anti-oxidative capacity, immunity, health, well-being, and tissue protein synthesis in gestating mammals (e.g. pigs).

\section{Compliance with ethics guidelines}

Tao-lin YUAN, Yu-hua ZHU, Meng SHI, Tian-tian LI, Na LI, Guo-yao WU, Fuller W. BAZER, Jian-jun ZANG, Feng-lai WANG, and Jun-jun WANG declare that they have no conflict of interest.

This article does not contain any studies with human or animal subjects performed by any of the authors.

\section{References}

Adashi, E.Y., Hsueh, A., Yen, S., 1981. Insulin enhancement of luteinizing-hormone and follicle-stimulating-hormone release by cultured pituitary-cells. Endocrinology, 108(4): 1441-1449. [doi:10.1210/endo-108-4-1441]

Anderson, L.L., 1978. Growth, protein content and distribution of early pig embryos. Anat. Rec., 190(1):143-153. [doi:10.1002/ar.1091900112]

Antipatis, C., Finch, A.M., Ashworth, C.J., 2008. Effect of controlled alterations in maternal dietary retinol on foetal and neonatal retinol status and pregnancy outcome in pigs. Livest. Sci., 118(3):247-254. [doi:10.1016/j.livsci.2008. 01.026]

Argente, M.J., Santacreu, M.A., Climent, A., et al., 2006. Influence of available uterine space per fetus on fetal development and prenatal survival in rabbits selected for uterine capacity. Livest. Sci., 102(1-2):83-91. [doi:10. 1016/j.livprodsci.2005.11.022]

Argente, M.J., Santacreu, M.A., Climent, A., et al., 2008. Effects of intrauterine crowding on available uterine space per fetus in rabbits. Livest. Sci., 114(2-3):211-219. [doi:10.1016/j.livsci.2007.05.008]

Arroyo, J.A., Winn, V.D., 2008. Vasculogenesis and angiogenesis in the IUGR placenta. Semin. Perinatol., 32(3): 172-177. [doi:10.1053/j.semperi.2008.02.006]

Ashworth, C.J., Antipatis, C., 1999. Effects of pre- and postmating nutrition on embryo survival in gilts. Reprod. Domest. Anim., 34(3-4):103-108. [doi:10.1111/j.14390531.1999.tb01226.x]

Ashworth, C.J., Beattie, L., Antipatis, C., et al., 1999. Effects of pre- and post-mating feed intake on blastocyst size, secretory function and glucose metabolism in Meishan gilts. Reprod. Fert. Dev., 11(6):323-327. [doi:10.1071/ RD99040]

Athorn, R.Z., Stott, P., Bouwman, E.G., et al., 2013. Effect of feeding level on luteal function and progesterone concentration in the vena cava during early pregnancy in gilts. Reprod. Fert. Dev., 25(3):531-538. [doi:10.1071/RD11 295]

Aucott, S.W., Donohue, P.K., Northington, F.J., 2004. Increased morbidity in severe early intrauterine growth restriction. J. Perinatol., 24(7):435-440. [doi:10.1038/sj.jp. 7211116]

Auldist, D.E., King, R.H., 1995. Piglets' role in determining milk production in the sow. In: Hennessy, D.P., Cranwell, P.D. (Eds.), Manipulating Pig Production V. Australasian Pig Science Association, Werribee, Australia, p.114-118.

Batshaw, M.L., Brusilow, S.W., 1978. Asymptomatic hyperammonemia in low-birth-weight infants. Pediatr. Res., 12(3):221-224. [doi:10.1203/00006450-197803000-00012]

Bazer, F.W., 2013. Pregnancy recognition signaling mechanisms in ruminants and pigs. J. Anim. Sci. Biotech., 4(1):23. [doi:10.1186/2049-1891-4-23]

Bazer, F.W., Thatcher, W.W., 1977. Theory of maternal recognition of pregnancy in swine based on estrogen controlled endocrine versus exocrine secretion of prostaglandin-f $2 \alpha$ by uterine endometrium. Prostaglandins, 14(2):397-401. [doi:10.1016/0090-6980(77)90185-X]

Bazer, F.W., Johnson, G.A., 2014. Pig blastocyst-uterine interactions. Differentiation, 87(1-2):52-65. [doi:10.1016/ j.diff.2013.11.005]

Bazer, F.W., Thatcher, W.W., Martinatbotte, F., et al., 1988. Conceptus development in large white and prolific Chinese Meishan pigs. J. Reprod. Fert., 84(1):37-42. [doi:10. 1530/jrf.0.0840037]

Bazer, F.W., Wu, G., Johnson, G.A., et al., 2014. Environmental factors affecting pregnancy: endocrine disrupters, nutrients and metabolic pathways. Mol. Cell. Endocrinol., 398(1-2):53-68. [doi:10.1016/j.mce.2014.09.007]

Bell, A.W., Ehrhardt, R.A., 2002. Regulation of placental nutrient transport and implications for fetal growth. Nutr. Res. Rev., 15(2):211-230. [doi:10.1079/NRR200239]

Bereskin, B., Shelby, C.E., Cox, D.F., 1973. Some factors affecting pig survival. J. Anim. Sci., 36(5):821-827. [doi:10.2134/jas1973.365821x]

Besenfelder, U., Solti, L., Seregi, J., et al., 1996. Different 
roles for B-carotene and vitamin A in the reproduction on rabbits. Theriogenology, 45(8):1583-1591. [doi:10.1016/ 0093-691X(96)00127-6]

Biensen, N.J., Wilson, M.E., Ford, S.P., 1998. The impact of either a Meishan or Yorkshire uterus on Meishan or Yorkshire fetal and placental development to days 70, 90, and 110 of gestation. J. Anim. Sci., 76(8):2169-2176.

Blachier, F., Davila, A.M., Benamouzig, R., et al., 2011. Channelling of arginine in $\mathrm{NO}$ and polyamine pathways in colonocytes and consequences. Front. Biosci. (Landmark Ed.), 16(1):1331-1343. [doi:10.2741/3792]

Blomberg, L.A., Long, E.L., Sonstegard, T.S., et al., 2005. Serial analysis of gene expression during elongation of the peri-implantation porcine trophectoderm (conceptus). Physiol. Genomics, 20(2):188-194. [doi:10.1152/physiolgenomics. 00157.2004]

Blomberg, L.A., Schreier, L., Li, R.W., 2010. Characteristics of peri-implantation porcine concepti population and maternal milieu influence the transcriptome profile. Mol. Reprod. Dev., 77(11):978-989. [doi:10.1002/mrd.21253]

Boshier, D.P., 1969. A histological and histochemical examination of implantation and early placentome formation in sheep. J. Reprod. Fert., 19(1):51-61. [doi:10.1530/jrf. 0.0190051]

Broekmans, F.J., Soules, M.R., Fauser, B.C., 2009. Ovarian aging: mechanisms and clinical consequences. Endocr. Rev., 30(5):465-493. [doi:10.1210/er.2009-0006]

Canario, L., Cantoni, E., Le Bihan, E., et al., 2006. Betweenbreed variability of stillbirth and its relationship with sow and piglet characteristics. J. Anim. Sci., 84(12):3185-3196. [doi:10.2527/jas.2005-775]

Canario, L., Lundgren, H., Haandlykken, M., et al., 2010. Genetics of growth in piglets and the association with homogeneity of body weight within litters. J. Anim. Sci., 88(4):1240-1247. [doi:10.2527/jas.2009-2056]

Coffey, M.T., Britt, J.H., 1993. Enhancement of sow reproductive-performance by $\beta$-carotene or vitamin-A. J. Anim Sci., 71(5):1198-1202.

Cossu, G., Borello, U., 1999. Wnt signaling and the activation of myogenesis in mammals. EMBOJ., 18(24):6867-6872. [doi:10.1093/emboj/18.24.6867]

Cox, N.M., Stuart, M.J., Althen, T.G., et al., 1987. Enhancement of ovulation rate in gilts by increasing dietary energy and administering insulin during follicular-growth. $J$ Anim. Sci., 64(2):507-516. [doi:10.2134/jas1987.642507x]

Cromi, A., Ghezzi, F., Raffaelli, R., et al., 2009. Ultrasonographic measurement of thymus size in IUGR fetuses: a marker of the fetal immunoendocrine response to malnutrition. Ultrasound Obst. Gyn., 33(4):421-426. [doi:10. 1002/uog.6320]

Damgaard, L.H., Rydhmer, L., Lovendahl, P., et al., 2003. Genetic parameters for within-litter variation in piglet birth weight and change in within-litter variation during suckling. J. Anim. Sci., 81(3):604-610.

Dewey, C.E., Martin, S.W., Friendship, R.M., et al., 1995. Associations between litter size and specific sow-level management factors in Ontario swine. Prev. Vet. Med., 23(1-2):101-110. [doi:10.1016/0167-5877(94)00427-K]

Dhindsa, D.S., Dziuk, P.J., 1968. Influence of varying the proportion of uterus occupied by embryos on maintenance of pregnancy in the pig. J. Anim. Sci., 27(3): 668-672. [doi:10.2134/jas1968.273668x]

Du, M., Tong, J., Zhao, J., et al., 2010. Fetal programming of skeletal muscle development in ruminant animals. $J$. Anim. Sci., 88(13 Suppl.):E51-E60. [doi:10.2527/jas.20092311]

EAAP, 2011. Book of Abstracts of the 62nd Annual Meeting of the European Association for Animal Production: Stavanger, Norway, Vol. 17, Wageningen Academic Pub.

Estany, J., Sorensen, D., 1995. Estimation of genetic-parameters for litter size in Danish-Landrace and Yorkshire pigs. Anim. Sci., 60(2):315-324. [doi:10.1017/S135772980000 8481]

Faber, J.J., Thornburg, K.L., 1983. Placental Physiology. Structure and Function of Fetomaternal Exchange. Raven Press, New York, p.1-192.

Fahmy, M.H., Bernard, C., 1971. Cause of mortality in Yorkshire pigs from birth to 20 weeks of age. Can. J. Anim. Sci., 51(2):351-359. [doi:10.4141/cjas71-048]

Ferguson, E.M., Ashworth, C.J., Edwards, S.A., et al., 2003. Effect of different nutritional regimens before ovulation on plasma concentrations of metabolic and reproductive hormones and oocyte maturation in gilts. Reproduction, 126(1):61-71. [doi:10.1530/rep.0.1260061]

Ferguson, E.M., Slevin, J., Edwards, S.A., et al., 2006. Effect of alterations in the quantity and composition of the pre-mating diet on embryo survival and foetal growth in the pig. Anim. Reprod. Sci., 96(1-2):89-103. [doi:10. 1016/j.anireprosci.2005.11.007]

Flint, A., Burton, R.D., Gadsby, J.E., et al., 1979. Blastocyst oestrogen synthesis and the maternal recognition of pregnancy. Ciba. Found. Symp., 64:209-238.

Ford, S.P., Reynolds, L.P., Magness, R.R., 1982. Blood flow to the uterine and ovarian vascular beds of gilts during the estrous cycle or early pregnancy. Biol. Reprod., 27(4): 878-885. [doi:10.1095/biolreprod27.4.878]

Fowden, A.L., Giussani, D.A., Forhead, A.J., 2005. Endocrine and metabolic programming during intrauterine development. Early Hum. Dev., 81(9):723-734. [doi:10.1016/ j.earlhumdev.2005.06.007]

Foxcroft, G.R., Dixon, W.T., Novak, S., et al., 2006. The biological basis for prenatal programming of postnatal performance in pigs. J. Anim. Sci., 84(13 Suppl.): E105-E112.

Foxcroft, G.R., Vinsky, M.D., Paradis, F., et al., 2007. Macroenvironment effects on oocytes and embryos in swine. Theriogenology, 68(Suppl. 1):S30-S39. [doi:10.1016/j. theriogenology.2007.04.032]

Fraser, D., Thompson, B.K., Ferguson, D.K., et al., 1979. The 'teat order' of suckling pigs: 3. Relation to competition within litters. J. Agric. Sci., 92(2):257-261. [doi:10. 1017/S0021859600062742] 
Gao, K., Jiang, Z., Lin, Y., et al., 2012. Dietary L-arginine supplementation enhances placental growth and reproductive performance in sows. Amino Acids, 42(6): 2207-2214. [doi:10.1007/s00726-011-0960-9]

García, M.L., Baselga, M., 2002. Estimation of genetic response to selection in litter size of rabbits using a cryopreserved control population. Livest. Prod. Sci., 74(1): 45-53. [doi:10.1016/S0301-6226(01)00280-9]

Gardner, D.S., Powlson, A.S., Giussani, D.A., 2001. An in vivo nitric oxide clamp to investigate the influence of nitric oxide on continuous umbilical blood flow during acute hypoxaemia in the sheep fetus. J. Physiol., 537(2): 587-596. [doi:10.1111/j.1469-7793.2001.00587.x]

Garreau, H., Bolet, G., Hurtaud, J., et al., 2004. Genetic homogenization of a character. Preliminary results of a canalising selection on the birth weight of young rabbits. ITEA Prod. Anim., 100A(3): 172-178 (in Spanish).

Geisert, R.D., Renegar, R.H., Thatcher, W.W., et al., 1982a. Establishment of pregnancy in the pig: I. Interrelationships between preimplantation development of the pig blastocyst and uterine endometrial secretions. Biol. Reprod., 27(4):925-939. [doi:10.1095/biolreprod27.4.925]

Geisert, R.D., Brookbank, J.W., Roberts, R.M., et al., 1982 b. Establishment of pregnancy in the pig: II. Cellular remodeling of the porcine blastocyst during elongation on Day 12 of pregnancy. Biol. Reprod., 27(4):941-955. [doi:10.1095/biolreprod27.4.941]

Geisert, R.D., Lucy, M.C., Whyte, J.J., et al., 2014. Cytokines from the pig conceptus: roles in conceptus development in pigs. J. Anim. Sci. Biotechnol., 5(1):51. [doi:10.1186/ 2049-1891-5-51]

Gill, J.C., Thomson, W., 1956. Observations on the behaviour of suckling pigs. Brit. J. Anim. Behav., 4(2):46-51. [doi:10.1016/S0950-5601(56)80022-1]

Giudice, L.C., 1992. Insulin-like growth-factors and ovarian follicular development. Endocr. Rev., 13(4):641-669.

Gondret, F., Lefaucheur, L., Louveau, I., et al., 2005. The long-term influences of birth weight on muscle characteristics and eating meat quality in pigs individually reared and fed during fattening. Arch. Tierzucht., 48: 68-73.

Greenberg, S.S., Lancaster, J.R., Xie, J.M., et al., 1997. Effects of NO synthase inhibitors, arginine-deficient diet, and amiloride in pregnant rats. Am. J. Physiol., 273(3): R1031-R1045.

Hammond, J.M., Mondschein, J.S., Samaras, S.E., et al., 1991. The ovarian insulin-like growth-factors, a local amplification mechanism for steroidogenesis and hormone action. J. Steroid Biochem. Mol. Biol., 40(1-3):411-416. [doi:10.1016/0960-0760(91)90209-N]

Hanahan, D., 1997. Signaling vascular morphogenesis and maintenance. Science, 277(5322):48-50. [doi:10.1126/ science.277.5322.48]

Harney, J.P., Mirando, M.A., Smith, L.C., et al., 1990. Retinolbinding protein - a major secretory product of the pig conceptus. Biol. Reprod., 42(3):523-532. [doi:10.1095/ biolreprod42.3.523]

Hayden, M.S., Ghosh, S., 2012. NF-B, the first quarter-century: remarkable progress and outstanding questions. Gene Dev., 26(3):203-234. [doi:10.1101/gad.183434.111]

Hazeleger, W., Ramaekers, P., Smits, C., et al., 2007. Influence of nutritional factors on placental growth and piglet imprinting. In: Wiseman, J., Varley, M.A., McOrist, S. (Eds.), Paradigms in Pig Science. Nottingham University Press, Nottingham, p.309-327.

Heap, R.B., Flint, A., Gadsby, J.E., et al., 1979. Hormones, the early embryo and the uterine environment. J. Reprod. Fert., 55(1):267-275. [doi:10.1530/jrf.0.0550267]

Hughes, P.E., 1998. Effects of parity, season and boar contact on the reproductive performance of weaned sows. Livest. Prod. Sci., 54(2):151-157. [doi:10.1016/S0301-6226(97) 00175-9]

Jobgen, W.S., Fried, S.K., Fu, W.J., et al., 2006. Regulatory role for the arginine-nitric oxide pathway in metabolism of energy substrates. J. Nutr. Biochem., 17(9):571-588. [doi:10.1016/j.jnutbio.2005.12.001]

Johnson, R.K., Nielsen, M.K., Casey, D.S., 1999. Responses in ovulation rate, embryonal survival, and litter traits in swine to 14 generations of selection to increase litter size. J. Anim. Sci., 77(3):541-557.

Kapell, D.N.R.G., Ashworth, C.J., Knap, P.W., et al., 2011. Genetic parameters for piglet survival, litter size and birth weight or its variation within litter in sire and dam lines using Bayesian analysis. Livest. Sci., 135(2-3):215-224. [doi:10.1016/j.livsci.2010.07.005]

Kemp, B., Soede, N.M., Helmond, F.A., et al., 1995. Effects of energy source in the diet on reproductive hormones and insulin during lactation and subsequent estrus in multiparous sows. J. Anim. Sci., 73(10):3022-3029.

Keys, J.L., King, G.J., Kennedy, T.G., 1986. Increased uterine vascular-permeability at the time of embryonic attachment in the pig. Biol. Reprod., 34(2):405-411. [doi:10. 1095/biolreprod34.2.405]

Kim, J., Burghardt, R.C., Wu, G., et al., 2011. Select nutrients in the ovine uterine lumen. VII. Effects of arginine, leucine, glutamine, and glucose on trophectoderm cell signaling, proliferation, and migration. Biol. Reprod., 84(1): 62-69. [doi:10.1095/biolreprod.110.085738]

Kim, S.W., Hurley, W.L., Han, I.K., et al., 2000. Growth of nursing pigs related to the characteristics of nursed mammary glands. J. Anim. Sci., 78(5):1313-1318.

Kim, S.W., Hurley, W.L., Wu, G., et al., 2009. Ideal amino acid balance for sows during gestation and lactation. $J$. Anim. Sci., 87(14 Suppl.):E123-E132. [doi:10.2527/jas. 2008-1452]

Kim, S.W., Weaver, A.C., Shen, Y.B., et al., 2013. Improving efficiency of sow productivity: nutrition and health. $J$. Anim. Sci. Biotechnol., 4(1):26. [doi:10.1186/2049-18914-26]

King, G.J., Atkinson, B.A., Robertson, H.A., 1982. Implantation and early placentation in domestic ungulates. $J$. Reprod. Fertil. Suppl., 31:17-30. 
King, R.H., Mullan, B.P., Dunshea, F.R., et al., 1997. The influence of piglet body weight on milk production of sows. Livest. Prod. Sci., 47(2):169-174. [doi:10.1016/ S0301-6226(96)01404-2]

Kiserud, T., Acharya, G., 2004. The fetal circulation. Prenatal Diag., 24(13):1049-1059. [doi:10.1002/pd.1062]

Knight, J.W., Bazer, F.W., Thatcher, W.W., et al., 1977. Conceptus development in intact and unilaterally hysterectomized-ovariectomized gilts: interrelations among hormonal status, placental development, fetal fluids and fetal growth. J. Anim. Sci., 44(4):620-637. [doi:10.2134/ jas1977.444620x]

Knol, E.F., Leenhouwers, J.I., van der Lende, T., 2002. Genetic aspects of piglet survival. Livest. Prod. Sci., 78(1): 47-55. [doi:10.1016/S0301-6226(02)00184-7]

Kong, X.F., Tan, B.E., Yin, Y.L., et al., 2012. L-Arginine stimulates the mTOR signaling pathway and protein synthesis in porcine trophectoderm cells. J. Nutr. Biochem., 23(9):1178-1183. [doi:10.1016/j.jnutbio.2011.06. 012]

Kong, X.F., Wang, X.Q., Yin, Y.L., et al., 2014. Putrescine stimulates the mTOR signaling pathway and protein synthesis in porcine trophectoderm cells. Biol. Reprod., 91(5):106. [doi:10.1095/biolreprod.113.113977]

Le Dividich, J., 1999. A review_neonatal and weaner pig: management to reduce variation. In: Manipulating Pig Production VII: Proceedings of the seventh biennial conference of the Australasian Pig Science Association (APSA). Adelaide, South Australia, p.135-155.

Le Dividich, J., Noblet, J., Herpin, P., et al., 1998. Thermoregulation. In: Wiseman, J., Varley, M.A., Chadwick, J.P. (Eds.), Progress in Pig Science. Nottingham University Press, p.229-263.

Le Dividich, J., Rooke, J.A., Herpin, P., 2005. Nutritional and immunological importance of colostrum for the new-born pig. J. Agric. Sci., 143(6):469-485. [doi:10.1017/S002 1859605005642]

Lee, G.J., Haley, C.S., 1995. Comparative farrowing to weaning performance in Meishan and Large White pigs and their crosses. Anim. Sci., 60(2):269-280. [doi:10. 1017/S1357729800008432]

Lei, J., Feng, D.Y., Zhang, Y.L., et al., 2012. Nutritional and regulatory role of branched-chain amino acids in lactation Front. Biosci. (Landmark Ed.), 17(7):2725-2739. [doi:10. 2741/4082]

Lei, J., Feng, D.Y., Zhang, Y.L., et al., 2013. Hormonal regulation of leucine catabolism in mammary epithelial cells. Amino Acids, 45(3):531-541. [doi:10.1007/s00726-0121332-9]

Li, W., Zhong, X., Zhang, L., et al., 2012. Heat shock protein 70 expression is increased in the liver of neonatal intrauterine growth retardation piglets. Asian Australas. J. Anim Sci., 25(8):1096-1101. [doi:10.5713/ajas.2012.12058]

Li, X., Bazer, F.W., Johnson, G.A., et al., 2010. Dietary supplementation with $0.8 \% \mathrm{~L}$-arginine between days 0 and 25 of gestation reduces litter size in gilts. J. Nutr.,
140(6):1111-1116. [doi:10.3945/jn.110.121350]

Li, X., Bazer, F.W., Johnson, G.A., et al., 2014. Dietary supplementation with L-arginine between days 14 and 25 of gestation enhances embryonic development and survival in gilts. Amino Acids, 46(2):375-384. [doi:10.1007/ s00726-013-1626-6]

Lin, G., Liu, C., Feng, C., et al., 2012. Metabolomic analysis reveals differences in umbilical vein plasma metabolites between normal and growth-restricted fetal pigs during late gestation. J. Nutr., 142(6):990-998. [doi:10.3945/ jn.111.153411]

Lin, G., Wang, X., Wu, G., et al., 2014. Improving amino acid nutrition to prevent intrauterine growth restriction in mammals. Amino Acids, 46(7):1605-1623. [doi:10.1007/ s00726-014-1725-z]

Liu, C., Lin, G., Wang, X., et al., 2013. Intrauterine growth restriction alters the hepatic proteome in fetal pigs. J. Nutr. Biochem., 24(6):954-959. [doi:10.1016/j.jnutbio.2012.06. 016]

Liu, X.D., Wu, X., Yin, Y.L., et al., 2012. Effects of dietary L-arginine or $\mathrm{N}$-carbamylglutamate supplementation during late gestation of sows on the miR-15b/16, miR-221/222, VEGFA and eNOS expression in umbilical vein. Amino Acids, 42(6):2111-2119. [doi:10.1007/ s00726-011-0948-5]

Lund, M.S., Puonti, M., Rydhmer, L., et al., 2002. Relationship between litter size and perinatal and pre-weaning survival in pigs. Anim. Sci., 74(2):217-222.

Matamoros, I.A., Cox, N.M., Moore, A.B., 1990. Exogenous insulin and additional energy affect follicular distribution, follicular steroid concentrations, and granulosa-cell human chorionic-gonadotropin binding in swine. Biol. Reprod., 43(1):1-7. [doi:10.1095/biolreprod43.1.1]

Mateo, R.D., Wu, G., Bazer, F.W., et al., 2007. Dietary L-arginine supplementation enhances the reproductive performance of gilts. J. Nutr., 137(3):652-656.

Maul, H., Longo, M., Saade, G.R., et al., 2003. Nitric oxide and its role during pregnancy: from ovulation to delivery. Curr. Pharm. Design, 9(5):359-380. [doi:10.2174/13816 12033391784]

McBride, G., 1963. The "teat order" and communication in your pigs. Anim. Behav., 11(1):53-56. [doi:10.1016/00033472(63)90008-3]

McCrabb, G.J., Harding, R., 1996. Role of nitric oxide in the regulation of cerebral blood flow in the ovine foetus. Clin. Exp. Pharmacol. Physiol., 23(10-11):855-860. [doi:10. 1111/j.1440-1681.1996.tb01133.x]

Meegdes, B.H., Ingenhoes, R., Peeters, L.L., et al., 1988. Early pregnancy wastage: relationship between chorionic vascularization and embryonic development. Fertil. Steril., 49(2):216-220

Milligan, B.N., Fraser, D., Kramer, D.L., 2001. Birth weight variation in the domestic pig: effects on offspring survival, weight gain and suckling behaviour. Appl. Anim. Behav. Sci., 73(3):179-191. [doi:10.1016/S0168-1591(01)00136-8] 
Milligan, B.N., Dewey, C.E., de Grau, A.F., 2002a. Neonatalpiglet weight variation and its relation to pre-weaning mortality and weight gain on commercial farms. Prev. Vet. Med., 56(2):119-127. [doi:10.1016/S0167-5877(02)00 157-5]

Milligan, B.N., Fraser, D., Kramer, D.L., 2002b. Within-litter birth weight variation in the domestic pig and its relation to pre-weaning survival, weight gain, and variation in weaning weights. Livest. Prod. Sci., 76(1-2):181-191. [doi:10.1016/S0301-6226(02)00012-X]

Nielsen, B., Su, G., Lund, M.S., et al., 2013. Selection for increased number of piglets at d 5 after farrowing has increased litter size and reduced piglet mortality. J. Anim. Sci., 91(6):2575-2582. [doi:10.2527/jas.2012-5990]

Père, M.C., Etienne, M., 2000. Uterine blood flow in sows: effects of pregnancy stage and litter size. Reprod. Nutr. Dev., 40(4):369-382. [doi:10.1051/rnd:2000105]

Perry, J.S., Rowell, J.G., 1969. Variation in foetal weight and vascular supply along the uterine horn of the pig. $J$. Reprod. Fertil., 19(3):527-534. [doi:10.1530/jrf.0.0190527]

Perry, J.S., Heap, R.B., Amoroso, E.C., 1973. Steroid hormone production by pig blastocysts. Nature, 245(5419):45-47. [doi:10.1038/245045a0]

Perry, J.S., Heap, R.B., Burton, R.D., et al., 1976. Endocrinology of the blastocyst and its role in the establishment of pregnancy. J. Reprod. Fertil. Suppl., (25):85-104.

Petters, R.M., Johnson, B.H., Reed, M.L., et al., 1990. Glucose, glutamine and inorganic-phosphate in early development of the pig embryo in vitro. J. Reprod. Fertil., 89(1): 269-275. [doi:10.1530/jrf.0.0890269]

Pettigrew, J.E., Cornelius, S.G., Moser, R.L., et al., 1986. Effects of oral doses of corn oil and other factors on preweaning survival and growth of pigs. J. Anim. Sci., 62(3):601-612.

Politis, I., Chronopoulou, R., 2008. Milk peptides and immune response in the neonate. In: Bösze, Z. (Ed.), Bioactive Components of Milk. Advances in Experimental Medicine and Biology. Vol. 606, Springer New York, p.253-269. [doi:10.1007/978-0-387-74087-4_10]

Pomeroy, R.W., 1960. Infertility and neonatal mortality in the sow. I. Lifetime performance and reasons for disposal of sows. J. Agric. Sci., 54(1):1-17. [doi:10.1017/S002185 9600021432]

Pond, W.G., Houpt, K.A., 1978. The Biology of the Pig. Comstock Pub. Associates, p.371.

Pope, W.F., Wilde, M.H., Xie, S., 1988. Effect of electrocautery of nonovulated day 1 follicles on subsequent morphological variation among day 11 porcine embryos. Biol. Reprod., 39(4):882-887. [doi:10.1095/biolreprod39.4.882]

Pope, W.F., Xie, S., Broermann, D.M., et al., 1990. Causes and consequences of early embryonic diversity in pigs. $J$. Reprod. Fertil. Suppl., 40:251-260.

Prunier, A., Dourmad, J.Y., Etienne, M., 1993. Feeding level, metabolic parameters and reproductive-performance of primiparous sows. Livest. Prod. Sci., 37(1-2):185-196. [doi:10.1016/0301-6226(93)90071-O]
Puppe, B., Tuchscherer, A., 1999. Developmental and territorial aspects of suckling behaviour in the domestic pig ( $\mathrm{Sus}$ scrofa f. domestica). J. Zool., 249(3):307-313. [doi:10. 1111/j.1469-7998.1999.tb00767.x]

Quesnel, H., Brossard, L., Valancogne, A., et al., 2008. Influence of some sow characteristics on within-litter variation of piglet birth weight. Animal, 2(12):1842. [doi:10.1017/S175173110800308X]

Quesnel, H., Farmer, C., Devillers, N., 2012. Colostrum intake: influence on piglet performance and factors of variation. Livest. Sci., 146(2-3):105-114. [doi:10.1016/j.livsci.2012. 03.010]

Quesnel, H., Quiniou, N., Roy, H., et al., 2014. Supplying dextrose before insemination and L-arginine during the last third of pregnancy in sow diets: effects on withinlitter variation of piglet birth weight. J. Anim. Sci., 92(4):1445-1450. [doi:10.2527/jas.2013-6701]

Quiniou, N., Dagorna, J., Gaudre, D., 2002. Variation of piglets birth weight and consequences on subsequent performance. Livest. Prod. Sci., 78(1):63-70. [doi:10.1016/ S0301-6226(02)00181-1]

Ran, R., Lu, A., Zhang, L., et al., 2004. Hsp70 promotes TNF-mediated apoptosis by binding IKK $\gamma$ and impairing NF-kB survival signaling. Genes Dev., 18(12):1466-1481. [doi:10.1101/gad.1188204]

Redmer, D.A., Wallace, J.M., Reynolds, L.P., 2004. Effect of nutrient intake during pregnancy on fetal and placental growth and vascular development. Domest. Anim. Endocrinol., 27(3):199-217. [doi:10.1016/j.domaniend.2004. 06.006]

Reynolds, L.P., Redmer, D.A., 1992. Growth and microvascular development of the uterus during early pregnancy in ewes. Biol. Reprod., 47(5):698-708. [doi:10.1095/biolreprod 47.5.698]

Reynolds, L.P., Redmer, D.A., 1995. Utero-placental vascular development and placental function. J. Anim. Sci., 73(6): 1839-1851.

Reynolds, L.P., Redmer, D.A., 2001. Angiogenesis in the placenta. Biol. Reprod., 64(4):1033-1040. [doi:10.1095/ biolreprod64.4.1033]

Reynolds, L.P., Magness, R.R., Ford, S.P., 1984. Uterine blood flow during early pregnancy in ewes: interaction between the conceptus and the ovary bearing the corpus luteum. J. Anim. Sci., 58(2):423-429.

Reynolds, L.P., Caton, J.S., Redmer, D.A., et al., 2006. Evidence for altered placental blood flow and vascularity in compromised pregnancies. J. Physiol., 572(1):51-58. [doi:10.1113/jphysiol.2005.104430]

Rezaei, R., Knabe, D.A., Li, X., et al., 2011. Enhanced efficiency of milk utilization for growth in surviving lowbirth-weight piglets. J. Anim. Sci. Biotechnol., 2(2):73-83.

Rezaei, R., Wang, W.W., Wu, Z.L., et al., 2013a. Biochemical and physiological bases for utilization of dietary amino acids by young pigs. J. Anim. Sci. Biotechnol., 4(1):7. [doi:10.1186/2049-1891-4-7]

Rezaei, R., Knabe, D.A., Tekwe, C.D., et al., 2013b. Dietary 
supplementation with monosodium glutamate is safe and improves growth performance in postweaning pigs. Amino Acids, 44(3):911-923. [doi:10.1007/s00726-0121420-x]

Robertson, J.A., 1997. Investigations of the action of vitamin A and $\beta$ carotene on reproductive performance in pigs. $\mathrm{PhD}$ Thesis, Victoria University of Technology, Australia.

Robertson, J.A., Towstoless, M.K., Ott, T.L., et al., 1997. Effect of retinol palmitate on ovarian follicle size and follicular hormone concentration in the gilt. Biol. Reprod., 56(1):452.

Rooke, J.A., Bland, I.M., 2002. The acquisition of passive immunity in the new-born piglet. Livest. Prod. Sci., 78(1): 13-23. [doi:10.1016/S0301-6226(02)00182-3]

Rosahn, P.D., Greene, H.S.N., 1936. The influence of intrauterine factors on the fetal weight of rabbits. J. Exp. Med., 63(6):901-921. [doi:10.1084/jem.63.6.901]

Ross, J.W., Ashworth, M.D., Hurst, A.G., et al., 2003. Analysis and characterization of differential gene expression during rapid trophoblastic elongation in the pig using suppression subtractive hybridization. Reprod. Biol. Endocrinol., 1(1):23. [doi:10.1186/1477-7827-1-23]

Savietto, D., Cervera, C., Rodenas, L., et al., 2014. Different resource allocation strategies result from selection for litter size at weaning in rabbit does. Animal, 8(4):618-628 [doi:10.1017/S1751731113002437]

Schweigert, F.J., Bonitz, K., Siegling, C., et al., 1999. Distribution of vitamin A, retinol-binding protein, cellular retinoic acid-binding protein $I$, and retinoid $X$ receptor $\beta$ in the porcine uterus during early gestation. Biol. Reprod., 61(4):906-911. [doi:10.1095/biolreprod61.4.906]

Self, J.T., Spencer, T.E., Johnson, G.A., et al., 2004. Glutamine synthesis in the developing porcine placenta. Biol. Reprod., 70(5):1444-1451. [doi:10.1095/biolreprod.103. 025486]

Sharpe, H.B., 1966. Pre-weaning mortality in a herd of Large White pigs. Brit. Vet. J., 122(3):99-111.

Soede, N.M., Noordhuizen, J.P.T.M., Kemp, B., 1992. The duration of ovation in pigs, studied by transrectal ultrasonography, is not related to early embryonic diversity. Theriogenology, 38(4):653-666. [doi:10.1016/0093-691X (92)90028-P]

Southwood, O.I., Kennedy, B.W., 1991. Genetic and environmental trends for litter size in swine. J. Anim. Sci., 69(8):3177-3182.

Stroband, H.W., van der Lende, T., 1990. Embryonic and uterine development during early pregnancy in pigs. $J$. Reprod. Fertil. Suppl., 40:261-277.

Su, G., Lund, M.S., Sorensen, D., 2007. Selection for litter size at day five to improve litter size at weaning and piglet survival rate. J. Anim. Sci., 85(6):1385-1392. [doi:10. 2527/jas.2006-631]

Thompson, B.K., Fraser, D., 1986. Variation in piglet weights: development of within litter variation over a 5-week lactation and effect of farrowing crate design. Can. J. Anim. Sci., 66(2):361-372. [doi:10.4141/cjas86-037]
Tokach, M.D., Pettigrew, J.E., Dial, G.D., et al., 1992. Characterization of luteinizing-hormone secretion in the primiparous, lactating sow-relationship to blood metabolites and return-to-estrus interval. J. Anim. Sci., 70(7):21952201.

Town, S.C., Putman, C.T., Turchinsky, N.J., et al., 2004. Number of conceptuses in utero affects porcine fetal muscle development. Reproduction, 128(4):443-454. [doi: 10.1530/rep.1.00069]

van den Brand, H., Soede, N.M., Schrama, J.W., et al., 1998. Effects of dietary energy source on plasma glucose and insulin concentration in gilts. J. Anim. Physiol. An. N., 79(1-5):27-32. [doi:10.1111/j.1439-0396.1998.tb00626.x]

van den Brand, H., Dieleman, S.J., Soede, N.M., et al., 2000. Dietary energy source at two feeding levels during lactation of primiparous sows: I. Effects on glucose, insulin, and luteinizing hormone and on follicle development, weaning-to-estrus interval, and ovulation rate. J. Anim. Sci., 78(2):396-404.

van den Brand, H., Soede, N.M., Kemp, B., 2006. Supplementation of dextrose to the diet during the weaning to estrus interval affects subsequent variation in within-litter piglet birth weight. Anim. Reprod. Sci., 91(3-4):353-358. [doi:10.1016/j.anireprosci.2005.04.009]

van den Brand, H., van Enckevort, L.C.M., van der Hoeven, E.M., et al., 2009. Effects of dextrose plus lactose in the sows diet on subsequent reproductive performance and within litter birth weight variation. Reprod. Domest. Anim., 44(6):884-888. [doi:10.1111/j.1439-0531.2008. 01106.x]

van der Lende, T., Dejager, D., 1991. Death risk and preweaning growth-rate of piglets in relation to the within-litter weight distribution at birth. Livest. Prod. Sci., 28(1):73-84. [doi:10.1016/0301-6226(91)90056-V]

van der Lende, T., Hazeleger, W., Dejager, D., 1990. Weight distribution within litters at the early fetal stage and at birth in relation to embryonic mortality in the pig. Livest. Prod. Sci., 26(1):53-65. [doi:10.1016/0301-6226(90)900 55-B]

Vonnahme, K.A., Wilson, M.E., Foxcroft, G.R., et al., 2002. Impacts on conceptus survival in a commercial swine herd. J. Anim. Sci., 80(3):553-559.

Waldorf, D.P., Foote, W.C., Sele, H.L., et al., 1957. Factory affecting fetal pig weight late in gestation. J. Anim. Sci., 4(16):976-985. [doi:10.2134/jas1957.164976x]

Walzem, R.L., Dillard, C.J., German, J.B., 2002. Whey components: millennia of evolution create functionalities for mammalian nutrition: what we know and what we may be overlooking. Crit. Rev. Food Sci. Nutr., 42(4):353-375. [doi:10.1080/10408690290825574]

Wang, J., Chen, L., Li, D., et al., 2008. Intrauterine growth restriction affects the proteomes of the small intestine, liver, and skeletal muscle in newborn pigs. J. Nutr., 138(1):60-66.

Wang, T., Liu, C., Feng, C., et al., 2013. IUGR alters muscle fiber development and proteome in fetal pigs. Front. 
Biosci. (Landmark Ed.), 18(2):598-607. [doi:10.2741/ 4123]

Wang, W.W., Wu, Z.L., Dai, Z.L., et al., 2013. Glycine metabolism in animals and humans: implications for nutrition and health. Amino Acids, 45(3):463-477. [doi:10. 1007/s00726-013-1493-1]

Wang, W.W., Wu, Z.L., Lin, G., et al., 2014. Glycine stimulates protein synthesis and inhibits oxidative stress in pig small-intestinal epithelial cells. J. Nutr., 144(10):15401548. [doi:10.3945/jn.114.194001]

Wang, X.Q., Frank, J.W., Xu, J., et al., 2014a. Functional role of arginine during the peri-implantation period of pregnancy. II. Consequences of loss of function of nitric oxide synthase NOS3 mRNA in ovine conceptus trophectoderm. Biol. Reprod., 91(3):59. [doi:10.1095/biolreprod.114.12 1202]

Wang, X.Q., Lin, G., Liu, C., et al., 2014b. Temporal proteomic analysis reveals defects in small-intestinal development of porcine fetuses with intrauterine growth restriction. J. Nutr. Biochem., 25(7):785-795. [doi:10.1016/ j.jnutbio.2014.03.008]

Webel, S.K., Dziuk, P.J., 1974. Effect of stage of gestation and uterine space on prenatal survival in pig. J. Anim. Sci., 38(5):960-963. [doi:10.2134/jas1974.385960x]

Wei, Y.Q., Zhao, X., Kariya, Y., et al., 1995. Inhibition of proliferation and induction of apoptosis by abrogation of heat-shock protein (HSP) 70 expression in tumor cells. Cancer Immunol. Immunother., 40(2):73-78. [doi:10. 1007/BF01520287]

Whaley, S.L., Hedgpeth, V.S., Britt, J.H., 1997. Evidence that injection of vitamin A before mating may improve embryo survival in gilts fed normal or high-energy diets. $J$. Anim. Sci., 75(4):1071-1077.

Whaley, S.L., Hedgpeth, V.S., Farin, C.E., et al., 2000. Influence of vitamin A injection before mating on oocyte development, follicular hormones, and ovulation in gilts fed high-energy diets. J. Anim. Sci., 78(6):1598-1607.

Widdowson, E.M., 1971. Intrauterine growth retardation in pig. I. Organ size and cellular development at birth and after growth to maturity. Neonatology, 19(4-6):329-340. [doi:10.1159/000240427]

Wientjes, J.G.M., Soede, N.M., van der Peet-Schwering, C.M.C., et al., 2012. Piglet uniformity and mortality in large organic litters: effects of parity and pre-mating diet composition. Livest. Sci., 144(3):218-229. [doi:10.1016/ j.livsci.2011.11.018]

Wigmore, P., Stickland, N.C., 1983. Muscle development in large and small pig fetuses. J. Anat., 137(Pt 2):235-245.

Wilson, M.E., Biensen, N.J., Youngs, C.R., et al., 1998. Development of Meishan and Yorkshire littermate conceptuses in either a Meishan or Yorkshire uterine environment to day 90 of gestation and to term. Biol. Reprod., 58(4):905-910. [doi:10.1095/biolreprod58.4.905]

Winters, L.M., Cummings, J.N., Stewart, H.A., 1947. A study of factors affecting survival from birth to weaning and total weaning weight of the litter in swine. J. Anim. Sci.,
6(3):288-296. [doi:10.2134/jas1947.63288x]

Wise, T., Roberts, A.J., Christenson, R.K., 1997. Relationships of light and heavy fetuses to uterine position, placental weight, gestational age, and fetal cholesterol concentrations. J. Anim. Sci., 75(8):2197-2207.

Wiseman, J., Varley, M.A., Chadwick, J.P., 1998. Progress in Pig Science. Nottingham University Press.

Wolf, J., Zakova, E., Groeneveld, E., 2008. Within-litter variation of birth weight in hyperprolific Czech Large White sows and its relation to litter size traits, stillborn piglets and losses until weaning. Livest. Sci., 115(2-3):195-205. [doi:10.1016/j.livsci.2007.07.009]

Wootton, R., Flecknell, P.A., Royston, J.P., et al., 1983. Intrauterine growth-retardation detected in several species by non-normal birth-weight distributions. J. Reprod. Fertil., 69(2):659-663. [doi:10.1530/jrf.0.0690659]

$\mathrm{Wu}, \mathrm{G} ., 2010$. Functional amino acids in growth, reproduction and health. Adv. Nutr., 1(1):31-37. [doi:10.3945/an.110. 1008]

Wu, G., 2013. Functional amino acids in nutrition and health. Amino Acids, 45(3):407-411. [doi:10.1007/s00726-0131500-6]

Wu, G., 2014. Dietary requirements of synthesizable amino acids by animals: a paradigm shift in protein nutrition. J. Anim. Sci. Biotechnol., 5(1):34. [doi:10.1186/20491891-5-34]

Wu, G., Morris, S.M., 1998. Arginine metabolism: nitric oxide and beyond. Biochem. J., 336(1):1-17.

Wu, G., Bazer, F.W., Tuo, W.B., et al., 1996. Unusual abundance of arginine and ornithine in porcine allantoic fluid. Biol. Reprod., 54(6):1261-1265.

Wu, G., Bazer, F.W., Wallace, J.M., et al., 2006. Board-invited review: intrauterine growth retardation: implications for the animal sciences. J. Anim. Sci., 84(9):2316-2337. [doi: 10.2527/jas.2006-156]

Wu, G., Bazer, F.W., Davis, T.A., et al., 2007. Important roles for the arginine family of amino acids in swine nutrition and production. Livest. Sci., 112(1-2):8-22. [doi:10.1016/ j.livsci.2007.07.003]

Wu, G., Bazer, F.W., Datta, S., et al., 2008. Proline metabolism in the conceptus: implications for fetal growth and development. Amino Acids, 35(4):691-702. [doi:10.1007/ s00726-008-0052-7]

Wu, G., Bazer, F.W., Davis, T.A., et al., 2009. Arginine metabolism and nutrition in growth, health and disease. Amino Acids, 37(1):153-168. [doi:10.1007/s00726-0080210-y]

Wu, G., Bazer, F.W., Burghardt, R.C., et al., 2010. Impacts of amino acid nutrition on pregnancy outcome in pigs: mechanisms and implications for swine production. $J$. Anim. Sci., 88(13 Suppl.):E195-E204. [doi:10.2527/jas. 2009-2446]

Wu, G., Bazer, F.W., Johnson, G.A., et al., 2011. Triennial Growth Symposium: important roles for L-glutamine in swine nutrition and production. J. Anim. Sci., 89(7): 2017-2030. [doi:10.2527/jas.2010-3614] 
Wu, G., Wu, Z.L., Dai, Z.L., et al., 2013a. Dietary requirements of "nutritionally nonessential amino acids" by animals and humans. Amino Acids, 44(4):1107-1113. [doi:10.1007/s00726-012-1444-2]

Wu, G., Bazer, F.W., Satterfield, M.C., et al., 2013b. Impacts of arginine nutrition on embryonic and fetal development in mammals. Amino Acids, 45(2):241-256. [doi:10.1007/ s00726-013-1515-z]

Wu, G., Bazer, F.W., Johnson, G.A., et al., 2013c. Maternal and fetal amino acid metabolism in gestating sows. Soc. Reprod. Fertil. Suppl., 68:185-198.

Wu, G., Bazer, F.W., Dai, Z., et al., 2014. Amino acid nutrition in animals: protein synthesis and beyond. Annu. Rev. Anim. Biosci., 2(1):387-417. [doi:10.1146/annurev-animal022513-114113]

Wu, W.Z., Wang, X.Q., Wu, G.Y., et al., 2010. Differential composition of proteomes in sow colostrum and milk from anterior and posterior mammary glands. J. Anim. Sci., 88(8):2657-2664. [doi:10.2527/jas.2010-2972]

Xie, S., Broermann, D.M., Nephew, K.P., et al., 1990. Ovulation and early embryogenesis in swine. Biol. Reprod., 43(2):236-240. [doi:10.1095/biolreprod43.2.236]

Yang, H., Foxcroft, G.R., Pettigrew, J.E., et al., 2000. Impact of dietary lysine intake during lactation on follicular development and oocyte maturation after weaning in primiparous sows. J. Anim. Sci., 78(4):993-1000.

Zak, L.J., Cosgrove, J.R., Aherne, F.X., et al., 1997. Pattern of feed intake and associated metabolic and endocrine changes differentially affect postweaning fertility in primiparous lactating sows. J. Anim. Sci., 75(1):208-216.

Zheng, C., Huang, C., Cao, Y., et al., 2009. Branched-chain amino acids reverse the growth of intrauterine growth retardation rats in a malnutrition model. Asian Australas. J. Anim. Sci., 22(11):1495-1503. [doi:10.5713/ajas.2009. 90127]

Zhong, X., Wang, T., Zhang, X., et al., 2010. Heat shock protein 70 is upregulated in the intestine of intrauterine growth retardation piglets. Cell Stress Chaperones, 15(3): 335-342. [doi:10.1007/s12192-009-0148-3]
Zhong, X., Li, W., Huang, X., et al., 2012. Impairment of cellular immunity is associated with overexpression of heat shock protein 70 in neonatal pigs with intrauterine growth retardation. Cell Stress Chaperones, 17(4): 495-505. [doi:10.1007/s12192-012-0326-6]

Ziecik, A.J., Kapelanski, W., Zaleska, M., et al., 2002. Effect of diet composition and frequency of feeding on postprandial insulin level and ovarian follicular development in prepubertal pigs. J. Anim. Feed Sci., 11(3):471-483.

\section{中文概要}

\section{题 目：母猪营养状态对仔猪初生重窝内变异的影响}

概 要: 本综述旨在总结仔猪初生重窝内变异对仔猪健 康、生长及生产管理造成的不利影响、形成因素、 以及改善窝内变异的措施。在现代化高产母猪养 殖中, 仔猪初生重窝内变异程度及低初生重猪的 比例大幅增加, 导致新生期存活率、生长性能大 大降低。初生重窝内变异的影响因素包括母猪排 卵率、卵子质量、排卵持续时间、胚胎附植能力、 子宫容积、胎盘体积和效率等; 品种差异对仔猪 初生重的均匀度也有很大影响。在妊娠的三个关 键阶段（断奶一配种间隔期、妊娠早期和妊娠后 期）进行针对性的营养调控有望一定程度上提高 窝内初生重均匀度。目前已被报道的包括: 在配 种前母猪日粮中添加葡萄糖或者维生素 A, 妊娠 后期添加谷氨酰胺均可改善仔猪初生重均匀度, 精氨酸以及支链氨基酸也有提高仔猪初生重一 致性的潜能。但总体而言, 目前相关研究相对较 少、潜在的分子机制仍不明确, 需要大量深入的 研究来加深对妊娠期母体与胎儿发育过程相关 生物学事件、营养素作用机制的理解, 为制定出 更加科学有效的母猪饲喂措施提供理论基础。

关键词: 窝内变异; 猪; 死亡率; 发病率; 生长性能; 母 猪营养 